\title{
Histological approaches to determination of stem cells in neural tube defects which are created experimentally
}

\section{Deneysel olarak \\ olușturulan defektlerinde kök hücrelerin nöral tüp konusunda histolojik yaklaşımlar belirlenmesi}

Zeynep Deniz Şahin İnan; Serpil Ünver Saraydın

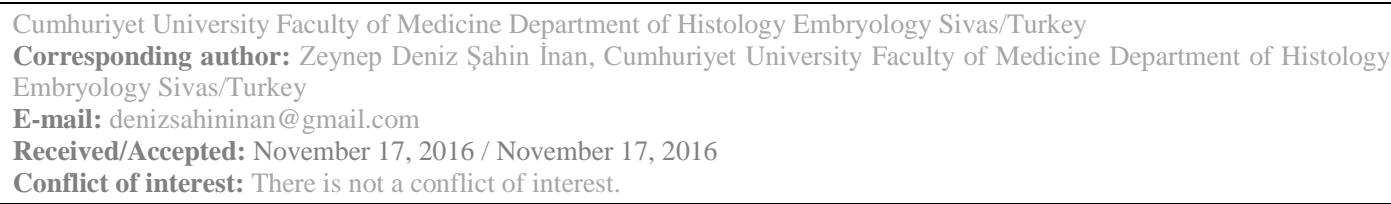

\begin{abstract}
SUMMARY
Stem cells are cells that are started to be seen in the early stages of development and they have important roles in development of both neural system and other systems. Anomalies that occur with the neural tubes inability to close are known as neural tube defects. Neural tube defects can be due to malfunction of gene area and many mechanisms since the moment neural tube starts to develop. The incidence of neural tube defect is very high in our country and in the world. Therefore, to understand the neural tube defects in the people, necessary data is usually collected by giving teratogen agent to subject animals. With this compilation, experimental neural tube defects have been formed and immunohistochemistry and immunofluorescent studies of some stem cells that are thought to have role in the formation of defect are compiled. From this point of view, it is aimed to determine the distributions of neural tube in rhe processes of normal development and defect formation, to understand the reproduction and alteration mechanisms of stem cells, and concomitantly to reveal the defect pathogenesis.
\end{abstract}

Keywords: neural tube defects, stem cells, immunohistochemistry, immunofluorescent

ÖZET

Kök hücreler gelişimin erken dönemlerinde görülmeye başlayan, hem sinir hem de diğer sistemlerin gelişiminde önemli rol alan hücrelerdendir. Nöral tüpün kapanmamasıla oluşan anomaliler nöral tüp defektleri olarak bilinir. Nöral tüp defekti oluşumu, nöral tüpün gelişmeye başladığı andan itibaren pek çok mekanizma ve gen bölgesinin işleyiş bozukluğuna bağli olabilir. Dünyada ve ülkemizde nöral tüp defekti insidansı oldukça yüksektir. Bu nedenle insanlarda meydana gelen nöral tüp defektini anlamak için genellikle deney hayvanlarına teratojen ajan verilerek gerekli bilgiler toplanır. Bu derlemeyle deneysel nöral tüp defekti oluşturulmuş ve defektin oluşumuda rol oynadığı düşünülen bazı kök hücrelerin immünhistokimya ve immünflorasan çalışmaları derlenmiştir. Buradan hareketle, kök hücre belirteçlerinden faydalanarak nöral tüpün normal gelişim ve defekt oluşum sürecindeki dağılımlarını belirlemek, kök hücrelerin çoğalma ve farklanma mekanizmalarını anlamayı ve beraberinde defekt patogenezinin ortaya çıkarılmasına katkı sağlayabilmes hedeflenmiştir.

Anahtar sözcükler: nöral tüp defektleri, kök hücreler, immünhistokimya, immünflorasan 


\section{INTRODUCTION}

Development process of neural tube is called neurulation. This process begins to develop approximately on the 17th day (beginning of the 3rd week) of the fertilization in humans, on the 8th day in mice and on the 8.5 th day in rats. ${ }^{1-4}$ With the occurrence of notochord and prechordal mesoderm, ectoderm that covers these areas thickens and thus neural plaque is formed. The hole which is between the neural folds forms the neural grooves in the continuation of neurulation process. Neurulation is completed with the closing of neuropores. Thus, central nervous system consists of large cephalic part where brain saccules are in and of a spinal cord which is a narrow part. While neurulation occurs, extracellular matrix elements and different gene areas play important roles. These are important in craniocaudal axis organization and in segmentation. They also have roles in regulation of expressions of various gene areas. ${ }^{4-6}$

Anomalies that occur with the neural tubes inability to close are called neural tube defects. A part of brain does not form when the neural tube in the cranial area cannot close. This type of defect is called anencephaly, and the defect that occurs as a result of inability to close in a place in tube's caudal is called spina bifida. Anencephaly and spina bifida has a large number of subtypes . ${ }^{4-7}$

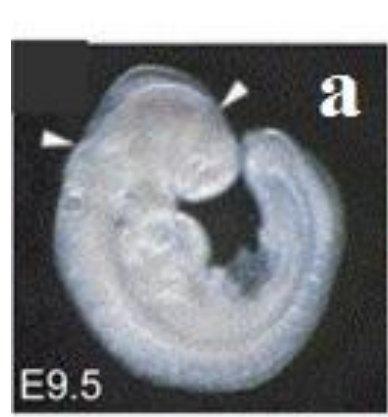

Kranlyal nörülasyon

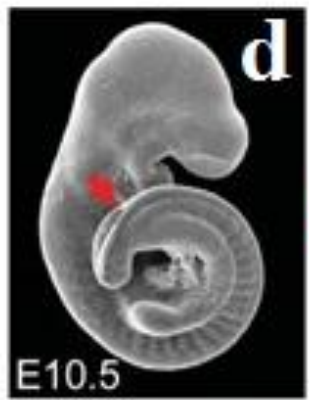

Spinal nórülasyon

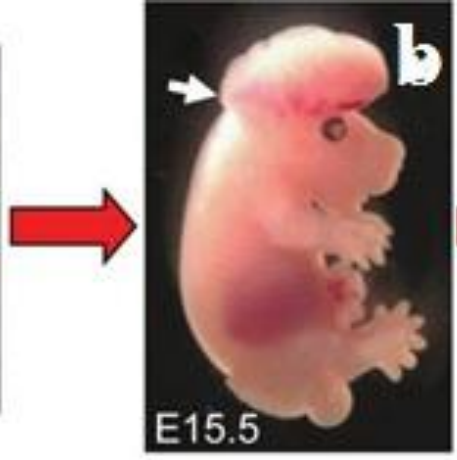

Eksensefali

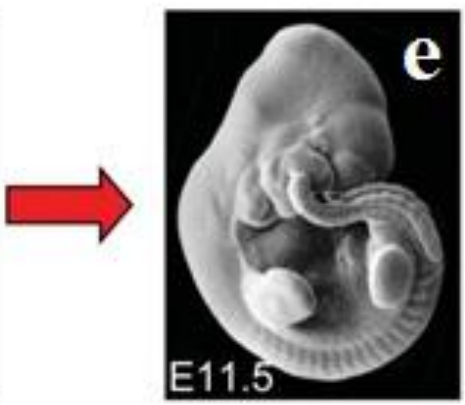

Erken spina bifida

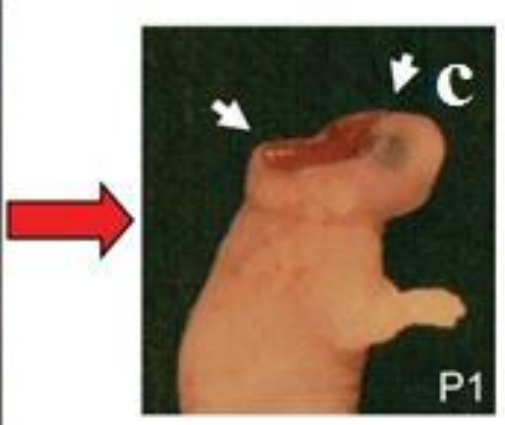

Anensefali

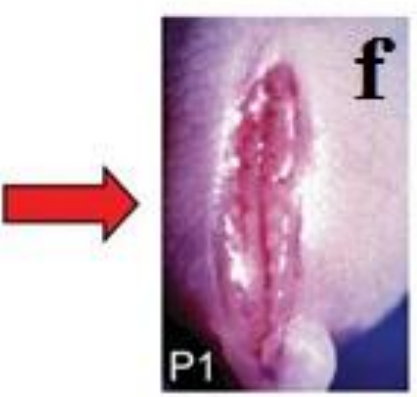

Myelo(meningo)sel

Figure 1. In mouse embryo a-c: open cranial defects, d-f: neural tube defects in spinal area (7). 
Neural tube defects can be due to malfunction of gene area and many mechanisms since the moment neural tube starts to develop. Although detailed epidemiological and experimental studies have been done for many years, etiology of neural tube defects is not completely understood. It is known that besides genetic factors, environmental factors are also effective in the development of neural tube defects. $^{4}$

It is stated that neural tube defects are different in different countries, different geographic areas and in different races. According to the studies done worldwide, frequency of neural tube defects is found between $0.057 \%$ and $1.387 \% \quad(4,8)$. Although there is insufficient data in our country, incidence of neural tube defect varies between approximately $0.15-0.63 \% .^{9}$ To understand the neural tube defects in humans, necessary data is obtained by applying genetic models, chemical models and surgical techniques to experimental animals. ${ }^{10}$ Many teratogenic causes neural tube defects in animals. Some of them are stated as; acetaldehyde, copper, cadmium, arsenic, neurotropic medications, valproic acid, methotrexate, fumonisins B1, insulin, papaverine, tunicamycin, high glucose and ketone substances, phenytoin, vitamin A, trypan blue, tiadiasol, maternal hyperglycemia, diazem, caffeine, local anesthetics, colchicine, betamercaptoethanol, retinoic acid and tetanus toxins. ${ }^{10,11}$

Stem cells are cells with the ability of divisibility for long time zones and the ability to renovate, to convert into unspecialized, various stem cells and to help damaged tissues gain its function. Stem cells are found widely in embryos since the early embryonal stages and in the later stages they alter. ${ }^{12,13}$ Today, intensely studied adult stem cells are hemopoietic stem cells, mesenchymal stem cells, neural stem cells, intestinal stem cells and endothelium stem cells. ${ }^{14}$ Arnold Caplan made a categorization by defining the 'mesenchymal stem cell' and another stem cell line that is similar 'hemopoietic stem cell' ${ }^{15}$ Stem cells are categorized according to $\mathrm{CD}$ (cluster of differentiation) types found on cell surfaces. Some of the genuine surfaces determinants of mesenchymal stem cells are stated as CD13, CD29, CD44, CD49e, CD73, CD90, CD105, CD146, CD166, CD271, SSEA4, Stro-1, W8B2/MSCA-1(15). Some of the genuine surfaces determinants of hemopoietic stem cells are CD11, CD14, CD31, CD34, CD45, CD117, HLA-DR. ${ }^{16,17}$

While neural tube defects are forming, they affect intracellular functioning mechanism by defecting functioning of many gene areas. In studies, in experimental neural tube defects that are formed by giving a excess retinoic acid, reproduction, alteration and metabolism of stem cells are affected..$^{18}$ Besides, activities of stem cells that are found in the neuroepithelial degenerates, anomalies such as axial rotations form in the embryo's developmental period. Also, vascular flow degenerates in the experimental neural tube defects that are formed by giving retinoic acid, new vessel formation mechanisms get affected and this causes a defect. ${ }^{19}$

Sulik K.K. ve Dehart D.B. stated in their study in 1988 that migration, cell metabolism and ectodermal cell reproduction of mesenchymal cells are affected with retinoic acid. ${ }^{20}$ Sulik K.K. and Alles A.J. showed in 1991 that giving retinol and metabolites excessively to various animal models caused similar defects. ${ }^{21}$ In another study, reproduction and apoptosis of neural progenitor cells that are found in the neuropithel in the neurulation process are compared in spina bifida that is formed with all-trans retinoic acid in foetal rats. When compared to control on the 11-13rd day of the embryonal period, excessive apoptosis is seen in the neuropithel and on the contrary very little neural progenitor cell reproduction is seen, and the reason of the defect is expressed with this study. ${ }^{18}$ In the study that examine excessive teratogen's impact on mouse pluripotent p19 cell lines, it is stated that there is an increase in the expression of enzymes in the teratogen metabolism and that Hox genes are actively working. ${ }^{22}$

Under normal conditions, 180 degree turning occurs from cranial to caudal in mice and rats in 5-15 somite phase (approximately 8-9th day) in-line. Turning that occurs other than this normal spin is called abnormal axial turning (neural tube twisting, kinking, abnormal axial turning). 
In a study done by Roger M.L. et al on teratogenic effect of trypan blue in 1985, abnormal axial turning is seen in mice that are applied $50 \mathrm{mg} / \mathrm{kg}$ trypan blue on the $8 \mathrm{th}$ day of embryonal period. ${ }^{23}$ In the study done by Miller P.N. et al in 1989, similar abnormal axial rotation is seen in the embryos they fed with folate deficient diet. $^{24}$

Researches have been done to reveal when pluripotent and multipotent stem cells turn into neural stem cells in the early embryonal period and which types of neural stem cells form the neural plaque. Studies have shown wide presence of embryonal stem cells in the early embryonal period, and have stated alteration in the later periods. It is shown that approximately more than $50 \%$ alive stem cells are found in rats in spinal neural tube, on the 8th day of embryonal period (E8) and that these cells are alive for 24 hours. $^{12,13}$ On the 10th day of embryonal period, stem cell ratio decreased from $20 \%$ to $5 \%$ in the telencephalon area in mouse brain. ${ }^{25}$ As embryonal period progresses, the number of stem cells rapidly decreases. In a study, stem cells that had been seen in the ratio of $10 \%$ in rat spinal cord in E12, decreased on the 1st day up to $\% 1$ after birth. ${ }^{12,13}$ In another study, it is stated that stem cells are small in number especially in some areas of the embryo. In mouse embryos, in E8,5, only $0.3 \%$ stem cells are marked in anterior neural plaque. ${ }^{26}$

As mentioned above, Kalyani et al. defined existing stem cells with various immunofluorescence dyeings on the 10,5 and 13,5th days of the embryonal period in their study done in $1997 . .^{13}$ These immunofluorescent determinants are roughly determinants such as nestin which is type $1 \mathrm{v}$ intercellular protein that provides axon development of neuron predecessors, $\alpha-\beta$ Tubulin to determine intracellular skeletal elements, NCAM (neural cell adhesion molecule, CD56) which is a adhesion molecule to determine neural stem cell predecessors. In their study in 2000, Qian et al benefited from stem cell cultures that they obtained from the embryonal mouse cerebral cortexes. ${ }^{25}$ In the study, to determine neuron predecessors $\alpha-\beta$, to determine Tubulin, Nestin, glial cell predecessors GFAP (Glial fibriler acid protein) and to determine oligodendrocite predecessors $\mathrm{O} 4$ antibodies are used and showed with immunohistochemical method - In the study done by Tropope et al on mouse embryos (1999), they determined EGFR (epithelial growth factor receptor) and FGFR (Fibroblast growth factor receptor) that are found on the stem cell surface as immunohistochemical and immunofluorescence besides nestin, anti $\beta$ III Tubulin, GFAP and O4 antibodies to determine stem cells in the early period. ${ }^{26}$ Cell surface molecules standard is called "cluster of differentiation" CD. Accordingly, many determinants found in $\mathrm{CD}$ group can be marked as immunohistochemistry,immunofluorescent in various phases of embryonal periods of mesenchymal and hemopoetic stem cells and predecessors. CD105 is a fast and quite good determinant in determination of cultured human mesenchymal stem cells. ${ }^{16}$ CD105 is a disulphid bound monodimeric membrane protein which is also known as endoglin, which weighs approximately 95 $\mathrm{kDa}$ and which belongs to TGF $\beta$ receptor complex.$^{16,27}$ Angiogenesis which is one of the main events in cardiovascular system development especially in embryonal period is important in regulation the migration route of erythrocytes, cytoskeleton organization and protecting the vitality. $^{27}$ In a study, intense hemorrhage, various embryonal and cardiovascular defects are seen on the 10.5th day of embryonal period in mouse embryos whose endoglin gene is blocked. ${ }^{28}$ At the same time, CD105 regulates extracellular matrix components (such as fibronectin, collagen, lumican). So, it is important in transmigration of mesenchymal stem cells, too. ${ }^{28}$ There are studies on expression of hemopoetik stem cells and neural stem cells besides mesenchymal stem cells. ${ }^{29} 10,5$ th day of the embrional period is the area that hemopoezin forms in aortic gonads mesonephros. In researches, it is expressed that CD105 is expressed from extraembrionic mesoderm and ectoderm in early gastrula period in mouse embryos, thus it is expressed that it has a potential role even in the earliest periods. ${ }^{30,31}$ In a study done in mouse embryos, immunolocalization in endothelial cells are stated in CD105 in E8,5-10,5. ${ }^{30}$ In study of 
Mancini et al in 2007, while endoglin was $75-85 \%$ localization ratio in E10,5 in mouse neural crista stem cells, it is stated that this rate rapidly decreased towards birth. Correlatively, while expression ratio of TGF $\beta$ is $88 \%$ in E10,5, it is $12 \%$ in adults. ${ }^{32}$ CD44 which is one of the markers that are used in determining mesenchymal stem cells, is the first identified, high polymorphic cell membrane glycoprotein. It is stated that CD44 expression is important especially in implantation and early embryonal development. ${ }^{33}$ In the study od Fenderson B.A et al. in 1993, it is stated that CD44 is started to be seen in decidual cells in blastocyst period after implantation. ${ }^{34}$ In a study, CD44 localization in chicken embryos was examined in 8-20 somite periods. In this study, firstly CD44 localization is seen in 5 somite phase, just after neural tube closes, along with the assuming that neural crista cells migrate to areas rich in hyaluronic acid, it is expressed that CD44 positive areas are first found in cephalic areas and then in tail bud mesenchyme. So, it is stated that CD44 is important in migration routes of neural crista cells. ${ }^{35}$ Also in they study done by Zhu et al in 2006, it is highlighted that CD44 have role in migration of mesenchymal cells by attaching hyalurana. ${ }^{36}$ Thus, impacts that might occur in the failure of this process will affect CD44 localization.

CD56 (NCAM, neural cell adhesion molecule) is a cell surface protein weighing approximately $140 \mathrm{kDa}$, which is known as neural cell adhesion molecule, which helps mesenchymal stem cell determination. ${ }^{37}$ It is found that it is expressed by subunits of mesenchymal cells that are rooted from bone marrow and it is revealed that it has an important role in reproduction of mesenchymal cells. ${ }^{38}$ In a study, it is determined that neural tube is open in mice whose CD56 gene is muted. It is shown with immunohistochemical markings that it is localized at high levels in neural tube's joint areas, in basal membrane, in neuropithel especially in early embryonal periods. In the same study, CD56 immunolocalization in similar areas in mutant mice could not be defined. ${ }^{39}$
Another determiner that is found on the surface of hemopoetik stem cells is CD45. CD45 is known as leukocyte antigen (Leucocyt common antigen, LCA). It weighs approximately $170-220 \mathrm{kDa}$, and it is a transmembrane glycoprotein. CD45 is found in mature $\mathrm{T}$ lymphocytes in adults. In addition, it is a cell surface determinant in all hemopoetic stem cells, thrombocytes and mature erythrocytes. ${ }^{16,40} \mathrm{CD} 45$ also has subunits which are expressed as RA, RB, RO. ${ }^{40}$ CD45 usually regulates intracellular relations by establishing relations between other cell surface molecules. Molecules that establish intracellular relations are cell surface proteins and carbohydrate units. One of its duties is to ensure neuron precursors development and reproduction, and the other duty is to regulate the development of neuron extensions. They also have important roles in formation of myelin structure. It is active in the developing neural system, in neurotransmitter modulation. ${ }^{41}$ It is first stated that p75 is expressed in human embryo, in blastosis' inner cell mass. Later E3,5 is also observed in mouse embryos in mRNA level ${ }^{42}$ Afterwards, it is determined that it is expressed from mesenchymal cells that are found in neural crista cells, endoderm, ectoderm and mesoderm during neurulation in humans, rats and mice. ${ }^{41}$ In a study done by Barcena et al in 2014, it is observed that CD45 localization increased in human fetuses from 5th week to the 9th week. Information about CD45 localization in neural tube defects is insufficient. ${ }^{43}$ However, it is stated that CD45 immunolocalization increased in brain tissue in pathological cranial neural system patients. ${ }^{44}$ It will be a possible result to expect increase in CD45 immunolocalization in neural tube defects.

\section{RESULTS}

Neural tube defect is formed with this compilation and immunohistochemistry and immunofluorescent studies of some stem cells that are thought to have role in the formation of defect are compiled. Neural tube defects are anomalies that occur due to neural tubes inability to close. Neural tube defects can be due to malfunction of gene area and many mechanisms since the 
moment neural tube starts to develop. The incidence of neural tube defects is very important in our country and in the world. Above mentioned studies are obtained by applying possible reasons of neural tube defects in people to animal experiments. One of the important techniques to determine stem cells in early and late embryonal period in neural tube defects is possible with the determination of these cells localisation throughout embryonal period. Immunohistochemical and immunofluorescent distributions of determinant that are just mentioned briefly above are important in determining stem cell reproduction and alteration mechanisms. In addition, it is thought that these studies will be beneficial in revealing defect pathogenesis and maybe in determination of new treatment processes.

\section{REFERENCES}

1. O'rahilly R, Müller F. Human growth during the embryonic period proper. Human Growth 1986; 245-253.

2. Sadler T.W. Mental retardation and developmental disabilities. Research Reviews 1998; 4: 247-253.

3. Padmanabhan R. Etiology, pathogenesis and prevention of neural tube deffects. Congenital Anomalies 2006; 46: 55-67.

4. $\mathrm{Au}$ K.S, Koch A.A, Northrup H. Epidemiologic and genetic aspects of spina bifida and other neural tube defects. Developmental disabilities 2010; 16: 6-15.

5. Copp A.J, Greene N.D.E, Murdoch J.N. Dishevelled: linking convergent extension with neural tube closure. Trends Neurosci. 2003; 26: 453-5.

6. Wallingford J.B. Neural tube closure and neural tube deffects: studies in animal models reveal known knowns and known unknowns. American Journal Of Medical Genetics Part C (Semin. Med. Genet.) 2005; 135c: 5968.

7. Copp A.J, Greene N.D. Neural tube defects disorders of neurulation and related embryonic processes.Wiley Interdiscip Rev Dev Biol. 2013; 2: 213-27.
8. Li Z, Ren A, Zhang L, Ye R, Li S, Zheng J, Hong S, Wang T. Extremely high prevalance of neural tube deffects in a 4 country area in shanxi province, China. Birth Deffects Research 2006; 76 (part a): 237-40.

9. Tunçbilek E. Türkiye'deki yüksek nöral tüp defekti sıklığını ve önlemek için yapılabilecekler. Çocuk Sağlığ1 ve Hastalıkları 2004; 47: 79-84.

10. Sim K-B, Lee J.Y, Phi J.H, Kim S.K, Wang K-C. Experimental models of spinal open neural tube defect and Chiari type II malformation Childs Nerv Syst 2013; 29: 1435-49.

11. Moise A.R, Noy N, Palczewski K, Blaner W.S. Delivery of retinoidbased therapies to target tissues. Biochemistry 2007; 46: 4449-58.

12. Kalyani A.J, Piper D, Mujtaba T, Lucero M.T, Rao M.S. Spinal cord neuronal precursors generate multiple neuronal phenotypes in culture. J Neurosci 1998; 18: 7856-68.

13. Kalyani A, Hobson K, Rao M.S. Neuroepithelial stem cells from the embryonic spinal cord: isolation, characterization, and clonal analysis. Dev Biol 1997; 186: 202-23.

14. Temple S. The development of neural stem cells. Nature 2001; 414: 112-18.

15. Caplan A.I. Mesenchymal stem cells. Journal of Orthopaedic Research 1991; 9: 641-50.

16. Sally A, Jones B. Markers for characterization of bone marrow multipotential stromal cells. Hindawi Publishing Corporation Stem Cells International. 2012; doi:10.1155/2012/975871.

17. Dominici M, Blanc K.L, Mueller I. Minimal criteria for defining multipotent mesenchymal stromal cells. The International Society for Cellular Therapy position statement. Cytotherapy 206; 8: 315-17.

18. Wei X, Hui Li H, Miao J, Zhou F, Liu B, Wu D, Li S, Wang L, Fan Y, Wang W. Disturbed apoptosis and cell proliferation in developing neuroepithelium of lumbo-sacral neural tubes in retinoic acid-induced spina bifida aperta in rat. Int $\mathrm{J}$ Devl Neuroscience 2012; 30: 375-81. 
19. Lai L, Bohnsack B.L, Niederreither K, Hirschi K.K. Retinoic acid regulates endothelial cell proliferation during vasculogenesis. Development 2003; 130: 6465-75.

20. Sulık K.K, Alles A.J. Teratogenicity of retinoids. In: SAUAT JH (ed.): Retinoids: 10 years On. Karger Basel 1991; 282-95.

21. Sulık K.K, Dehart D.B. Retinoic-acidinduced limb malformations resulting from apical ectodermal ridge cell death. Teratology 1988; 37: 527-37.

22. Chen Y, David H. Reese A Screen for Disruptors of the Retinol (Vitamin A) Signaling Pathway Birth Defects Research (Part B) 2013; 98: 276-282.

23. Rogers J.M, Daston G.P, Ebron M.T, Carver B, Stefanadis J.G, Grabowskı C.T. Studies on the mechanism of trypan blue teratogenicity in the rat developing in vivo and in vitro. Teratology 1985; 31: 389-99.

24. Miller P.N, Pratten M.K, Beck F. Growth of 9.5-day rat embryos in folic acid-deficient serum. Teratology, 1989; 391: 375-85.

25. 25. Qian X, Shen Q, Goderie S.K, He W, Capela A, Davis A.A, Temple S. Timing of CNS cell generation: a programmed sequence of neuron and glial cell production from isolated murine cortical stem cells. Neuron 2000; 28: 69-80.

26. Tropepe V, Sibilia M, Ciruna B.G, Rossant J, Wagner E.F, Van Der Kooy D. Distinct neural stem cells proliferate in response to EGF and FGF in the developing mouse telencephalon. Dev. Biol. 1999; 208: 166-88.

27. Mark P, Kleinsorge M, Gaebel R, Lux C.A, Toelk A, Pittermann E, David R, Steinhoff G, Ma N. Human mesenchymal stem cells display reduced expression of CD105 after culture in serum free medium. Stem Cells International 2013; 698076: 1-9.

28. Kitabayashi A.N, Andersona G.A, Sleepa G, Mena J, Karabegovic A, Karamatha S, Letarte M, Puri M.C. Endoglin is dispensable for angiogenesis, but required for endocardial cushion formation in the midgestation mouse embryo.
Developmental Biology 2009; 335: 66-77.

29. Chen C.Z, Li M, de Graaf D, Monti S, Gottgens B, Sanchez M.J, Lander E.S, Golub T.R, Green A.R, Lodish H.F. Identification of endoglin as a functional marker that defines longterm repopulating hematopoietic stem cells. Proc. Natl. Acad. Sci. U.S.A. 2002; 99: 15468-73.

30. Hirashima M, Bernstein A, Stanford W. L, Rossant J. Genetrap expression screening to identify endothelialspecific genes. Blood 2004; 104: 7118.

31. Ema M, Yokomizo T, Wakamatsu A, Terunuma T, Yamamoto M, Takahashi S. Primitive erythropoiesis from mesodermal precursors expressing Vecadherin, PECAM-1, Tie2, endoglin, and CD34 in the mouse embryo. Blood 2006; 108: 4018-24.

32. Mancini M.L, Verdi J.M, Conley B.A, Nicola T, Spicer D.B, Oxburgh L.H., Vary C.P. Endoglin is required for myogenic differentiation potential of neural crest stem cells. Dev Biol 2007; 308: 520-33.

33. Campbell S, Swann H.R, Aplin J.D, Seif M.W, Kimber S.J, Elstein M. CD44 is expressed throughout preimplantation human embryo development. Human Reproduction 1995; 10: 425-30.

34. Fenderson B.A, Stamenkovic I, Aruffo A. Localization of hyaluronan in mouse embryos during implantation, gastrulation and organogenesis. Differentiation. 1993; 54: 85-98.

35. Corbela C, Lehmanna A, Davison F. Expression of CD44 during early development of the chick embryo. Mechanisms of Development 2000; 96: 111-14.

36. Zhu H, Mitsuhashi N, Klein A. The role of the hyaluronan receptor CD44 in mesenchymal stem cell migration in the extracellular matrix. Stem Cells 2006, 24: 928-35.

37. Kusafuka K, Hirobe $K$, Wato $M$, Tanaka A, Nakajima T. CD56 expression is associated with neuroectodermal differentiation in ameloblastomas: an immunohistochemical evaluation in 
comparison with odontogenic cystic lesions. Med Mol Morphol. 2011; 44: 79-85.

38. Battula V.L,Treml S, Bareiss P.M, Gieseke F, Roelofs H, Zwart P, Müller I, Schewe B, Skutella T, Fibbe W.E, Kanz L, Bühring H.J. Isolation of functionally distinct mesenchymal stem cell subsets using antibodies against CD56, CD271 and mesenchymal stem cell antigen-1. Haematologica 2009; 94: 173-85.

39. Moase C.E, Trasler D.G. N-CAM alterations in splotch neural tube defect mouse embryos. Development 1991; 113: 1049-58.

40. Craig W, Poppema S, Little M.T, Dragowska W, Lansdorp P.M. CD45 isoforms expression on human haemopoietic cells et different stages of development. British Journal of Haematolog 1994; 88: 24-30.

41. Tomellini E, Lagadec C, Polakowska R, Bourhis X.L. (2014) Role of p75 neurotrophin receptor in stem cell biology: more than just a marker. Cell. Mol. Life Sci. 2014; 71: 2467-81.

42. 42. Moscatelli I, Pierantozzi E, Camaioni A, Siracusa G, Campagnolo L. p75 neurotrophin receptor is involved in proliferation of undifferentiated mouse embryonic stem cells. Exp Cell Res. 2009; 315: 3220-32.

43. Bárcena A, Kapidzic M, Muench M.O, Gormley M, Scott M.A, Weier J.F, Ferlatte C, Fisher S.J. The human placenta is a hematopoietic organ during the embryonic and fetal periods of development Dev Biol. 2014; 388: 216-19.

44. Penninger J.M, Sasaki J.I, Sasaki T, Oliveira-dos Santos A.J. CD45:new jobs for an old acquaintance. Nat Immunol. 2001; 2: 389-96. 